\title{
Liquidity Constraints and Investment in Transition Economies: The Case of Bulgaria
}

\author{
Nina Budina, Harry Garretsen and Eelke de Jong ${ }^{1}$
}

\footnotetext{
${ }^{1}$ First author: World Bank, Washington DC USA, second and third author: Department of Applied Economics, University of Nijmegen, The Netherlands. We would like to thank Elmer Sterken for the provision of the data-set and for useful comments on a previous version, we also would like to thank Robert-Paul Berben, Kyle Peters, the editor and three anonymous referees for their comments and suggestions. The opinions expressed are entirely those of the authors and do not necessarily represent the views of the World Bank.
} 


\title{
Liquidity Constraints and Investment in Transition Economies: The Case of Bulgaria
}

\begin{abstract}
We use Bulgarian firm level data to investigate the impact of liquidity constraints on investment performance. Internal funds are an important determinant of investment in most industrialized countries. We test whether internal funds are important for firm investment during the current transition process in Bulgaria. We use a simple accelerator model of investment to test whether liquidity constraints are relevant in the case of Bulgaria. Our estimations are based on data for the period 1993-1995, prior to the Bulgarian financial crisis in 1996-97. It turns out that Bulgarian firms are liquidity constrained, and that firms' size and financial structure help to distinguish between firms that are more and less liquidity constrained. In our view liquidity constraints can be given a different interpretation in the case of transition economies as compared to Western economies. A more in depth analysis of the data reveals that liquidity constraints and consequently the access to external funds for Bulgarian firm investment are to be seen against the background of soft-budget constraints and the failure of the financial system to enforce an efficient allocation of funds. In our view the lack of liquidity constraints may actually been seen as a sign of financial weakness in the case of Bulgaria.
\end{abstract}




\section{Introduction}

An efficient selection of investment projects is essential for sustained economic growth. In centrally planned economies this selection process is biased towards large-scale investment projects and disregards private incentives. Whereas in a centrally planned economy the decision process about investment can be characterized as top-down, in the (ideal-type) market economy the opposite holds. Investment is carried out by the individual firm and the firm itself decides whether to invest or not. In general the firm is not able or willing to finance the entire investment with internal funds. Hence, banks and capital markets are called upon to provide external funds and thereby take part in the selection process of investment projects.

Given the economic importance of investment, it is clear that in the transition process of the formerly socialist countries in Central and Eastern Europe (CEE) the introduction of market incentives is crucial. One way to stimulate this is to have a financial system that allocates financial resources efficiently (Berglof and Roland, 1998, p. 18). It is therefore relevant to know whether the reforms have been successful (yet) in this respect. Roughly speaking two methods can be distinguished for the investigation of the success of the process of transition to market economy. The first is to conduct a survey among managers of industrial firms and financial institutions. Such a survey can investigate whether or not managers in transition economies still behave in line with the incentives typical of the centrally planned economy or whether they have changed their modes of behaviour and act nowadays more in accordance with the incentives of market economy. Examples of these survey studies are Pinto, Belka and Krajewski (1993) and Pinto and van Wijnbergen (1994).

The second approach for investigating the relationship between investment and finance in the transition process is to estimate an investment function. These studies use firm-level data to investigate whether investment is financially or liquidity constrained and whether the empirical relationship between investment and liquidity constraints corresponds with that found in similar studies of market economies. Examples of this type of studies are Lizal (1996), Anderson and Kegels (1997), and Lensink and Sterken (1998). 
Most empirical studies of the transition process are restricted to those economies in CEE, which are characterized as radical reformers (Åslund et al., 1996). This leaves room for an investigation of the performance of more gradual reformers such as Hungary, Bulgaria and Russia (see for instance Perotti and Gelfer (1997) for Russia). In the present paper, we focus on the relevance of financial market imperfections for investment in Bulgaria. We estimate an investment function for Bulgarian firms and focus on the question whether investment is liquidity constrained. We subsequently look at the question whether particular Bulgarian firms in our sample are more liquidity constrained than other firms. Given the institutional differences between transition and market economies we also discuss in which way the interpretation of our estimation results in the case of Bulgaria might differ from that for long-established Western market economies. In our view the underlying behavior of firms and financial institutions in Bulgaria is at odds with the standard interpretation given to the role of liquidity constraints for investment. In fact, we do think that our estimation results provide support for the idea that financial system distortions continue to play a major role in the allocation of funds due to soft-budget constraints (SBCs). ${ }^{2}$

This paper is organized as follows. 2 presents a quick reminder of the theoretical underpinnings of the relevance of financial market imperfections for investment. 3 briefly deals with some institutional features of the Bulgarian case and also introduces our data set. 4 presents the full-sample estimation results of our accelerator model of investment. In Section 5 firm characteristics with respect to size and financial structure are used to see how firms differ in their sensitivity of investment to changes in cash flow, our liquidity variable. We present the sub-sample results based on these firm characteristics and interpret the results from the perspective of an inefficient financial system that is still plagued by SBCs. Section 6 concludes.

\section{Investment and liquidity constraints}

Firms can finance their investment by external funds by issuing equity or debt. Alternatively the firm can also use internal funds to finance its investment projects. Modigliani and Miller (1958) have shown long ago that in case of perfect capital markets

\footnotetext{
${ }^{2}$ Some often used definitions of soft-budget constraints can be found in Schaffer (1998).
} 
the firm's financial structure is irrelevant since the market value of the firm depends only on the expected profit stream from the investment project and not the financial structure. Firms are thus indifferent between the various (internal and external) means to finance their investment. Investment projects will be carried out if their expected return exceeds the (given) cost of capital which is thought to be the same for all firms. In this neoclassical view of financial markets, internal and external funds are perfect substitutes and investment can never be constrained by a lack of internal finance. There are, of course, many reasons for this irrelevance theorem not to hold in reality but one of its most important deficiencies is the assumption of perfect information. Instead, financial markets are better characterized by the existence of asymmetric information between the borrowers and lenders of external funds (Hubbard (1998). As almost any basic textbook nowadays explains, asymmetric information leads to problems of adverse selection and moral hazard.

What matters for our present purposes is that these problems of asymmetric information lead to a difference between the costs of internal and external funds. The providers of external finance will require a (firm specific) premium because they are unable to monitor or screen all aspects of the investment projects. The size of the external finance premium depends on firm characteristics, like firm size or net worth, which provide an (imperfect) indication for the lender of the creditworthiness of the borrowing firm. ${ }^{3}$ Due to the external finance premium, firms will, albeit to a different degree, prefer to finance their investment by internal funds. The upshot is that internal and external finance are no longer perfect substitutes. As a consequence, investments of firms facing high information costs are not only determined by expected profits but also potentially by the availability of internal funds. Investments of those firms expected to face higher (lower) information costs are thought to be more (less) constrained by the availability of internal finance. This basic idea underlies various empirical studies on the severity of liquidity constraints for investment (e.g. Fazzari, Hubbard and Petersen (1988), Chirinko (1993) or van Ees and Garretsen (1994)). The reduced form investment equation estimated in this type of studies, has the following general form (Hubbard, 1998, p. 202):

\footnotetext{
${ }^{3}$ This premium can be seen as credit rationing by price, it is, of course, also possible that the information problems lead to quantity rationing of external funds for firms, see Stiglitz and Weiss (1981).
} 


$$
(\mathrm{I} / \mathrm{K})_{\mathrm{i}}=\mathbf{c}_{0}+\mathbf{c}_{1} \mathbf{f}(\mathrm{X} / \mathrm{K})_{\mathrm{i}}+\mathbf{c}_{2} \mathbf{g}(\mathrm{L} / \mathrm{K})_{\mathrm{i}}+\varepsilon_{\mathrm{i}}
$$

where $i$ denotes the $i^{\text {th }}$ firm, $I_{i}$ is gross investment, $X_{i}$ denotes all the standard variables that determine the investment opportunities, $\mathrm{L}_{\mathrm{i}}$ represents the liquidity variables, $\varepsilon_{\mathrm{i}}$ is the error term and $\mathrm{K}_{\mathrm{i}}$, the scalar, is the capital stock of a firm $\mathrm{i}$ (at the beginning of each year). The liquidity variables are assumed to be uncorrelated with the investment opportunities. A positive and significant coefficient of the liquidity variable, $\mathbf{c}_{2}$, is thought to indicate that liquidity constraints matter to the extent that investment is sensitive to fluctuations in internal finance (in case of perfect capital markets, our benchmark, the liquidity coefficient would be insignificantly different from zero). In order to identify "constrained" and "unconstrained" firms, the equation mentioned above is estimated for sub-samples where the sub-sampling is based on theoretical priors with respect to the fact which firms are more likely to be liquidity constrained. Often used characteristics for an a priori grouping of firms are the firm's size, its age, the relationship with financiers or leverage (Hubbard, 1998, p. 201). The basic test is than to see whether the liquidity coefficient is significantly higher/lower for the supposedly more/less constrained group of firms. Before we turn to our specification of equation (1), we will first go into the transition process in Bulgaria and introduce our data set.

\section{Bulgaria: Financial Sector and Data Set}

\subsection{Banking System Reforms, Enterprise Debt and Soft Budget Constraints}

After a promising start in 1991-92 when prices, the exchange rate, and interest rates were liberalized, structural reforms in Bulgaria have stalled and most of the industrial production as well as the banking system was still in state hands. Many loss making (state) enterprises were kept afloat by bank credit. Public indebtedness grew as the losses of the firms and of the banks spilled into the public budget. Periodic attempts to stabilize the economy succeeded temporarily but were eventually undone by the failure to follow through with structural reform. Moreover, many stabilization measures consisted of unconditional financial bailout operations. As a result non-payment of dues became contagious, affecting even financially sound companies which, in principle did not have 
liquidity problems (Dobrinsky et al., 1997, p. 12). Finally, in 1996 the public lossed confidence in the bankingsystem and Bulgaria had to face a financial. Inflation, which in 1995 declined from $122 \%$ in 1994 to $32 \%$, increased sharply to more than $300 \%$ in 1996. The leva depreciated from 71 per U.S. dollar at the end of 1995 to 487 per U.S. dollar at the end of 1996 (IMF (1997)). Radical reforms turned out to be possible only after the election of 1997, but it is too early to tell about the effects of these reforms and our data set ends in 1996. In this subsection we will provide some background information on the state of affairs in the Bulgarian financial sector in these first years of the transition process. As will become clear in Section 5, this information is important for the interpretation of our estimation results.

At the start of the transition process Bulgaria essentially had a mono-bank system and there were no non-bank financial institutions with the exception of a few insurance agencies. In 1990 the mono-bank system was transformed into a two-tier banking system, consisting of a central bank responsible for the monetary policy and the supervision of commercial banks. ${ }^{4}$ Manchev (1996) and Nenova et al (1998) analyze the structural policy of the Bulgarian national bank, $\mathrm{BNB}$, and the government towards the financial sector of the economy in the post-1990 period. According to Manchev (1996), a factor that contributed strongly to the build-up of Bulgaria's banking crisis of 1996-1997 was the BNB's licensing policy. During the period 1990-1992 the BNB issued 14 licenses for new private (universal) banks and 59 licenses for the former regional branches of the BNB, which were transformed to private banks at the end of 1990. In deciding about these licenses little to no weight was given to the capital adequacy of the banks nor were loan classifications required. Furthermore, there were no liquidity requirements, internal bank control was not a real issue, and the licensing policy was not conditional upon the capacities of the banks' managers. ${ }^{5}$

Besides these newly created banks, there were also 8 state-owned banks that continued to exist. At the end of 1990, these state-owned banks held 85 percent of the

\footnotetext{
$4 \quad$ Non-bank financial institutions (without insurance companies and pension funds) were created since 1991 but their share was still insignificant as compared to the banking system: the share of non-bank financial companies in total banks' assets was 0.5 and 1.6 percent in 1993 and 1994 respectively.
} 
total bank capital and 96 percent of total bank assets, whereas in 1995 these ratios were 70.7 and 72.6 percent respectively. State-owned banks thus dominated the banking system in Bulgaria. These banks in particular inherited the non-performing debt of state owned enterprises. As Manchev (1996) point out, "State-owned banks are forced to restructure or to convert even short-term credits of state enterprises into long -term loans, because the latter use them (the short-term-credits) to finance (inappropriate) activities, which cannot be prevented by banks without incurring significant losses." (Manchev, 1996, p.40)

In dealing with the bad loans of state owned enterprises Bulgaria had to face the fact that the ratio of bank loans to GDP was much higher in Bulgaria than in other transition countries like Poland or Hungary. This meant that relatively larger expenditures were needed to clean up the bank portfolios. According to Thorn (1993), potential budgetary expenditures for cleaning up bank portfolios in mid-1991 in Bulgaria were amongst the highest (17.7 percent of GDP) in CEE. Potential non-performing loans in Bulgaria in 1991 were a staggering 44 percent of total loans extended by the banking system. In the following years Bulgarian (state) banks continued to provide finance services to state owned enterprises. This reinforced and exacerbated the moral hazard problem in the economy (Dewatripont and Roland, 1999). Despite substantial government resources to clean up bad debts of state-owned enterprises, the inefficient banking sector structure and the imprudent licensing policy of the BNB stimulated a further accumulation of non-performing loans.

To illustrate the debt position of Bulgarian firms, Table 1 shows the long term and short term debt (as shares of firms' capital) for 1993 - 1996. The ratio of long term debt to capital initially falls, this is due to clean up of bank portfolios but it than rises sharply in 1995. Note that Table 1 suggests that the distribution of long-term debt is probably very skewed. We will return to this issue in Section 5. The short-term debt to capital ratio clearly rises during the period 1993-1996 and this reflects the fact Bulgarian firms relied excessively on short-term debt to finance their activities with the result that the mean short-term debt to capital ratio had reached 1.53 in 1996.

\footnotetext{
${ }^{5}$ Due to the lack of prudent regulation and control during this period, Bulgarian commercial banks were seriously undercapitalized - at the end of 1990 the aggregate share of commercial banks' own capital in their aggregate total liabilities was only 3.3 percent.
} 
Table 1 The Level of indebtedness of Bulgarian Enterprises

\begin{tabular}{l|cccc}
\hline & 1993 & 1994 & 1995 & 1996 \\
\hline $\begin{array}{l}\text { Long term debt to capital } \\
\text { a. mean }\end{array}$ & 0.12 & 0.12 & 0.06 & 0.35 \\
$\quad$ b. median & 0.00 & 0.00 & 0.00 & 0.00 \\
Short-term debt to capital & & & & \\
a. mean & 0.48 & 0.57 & 0.75 & 1.53 \\
b. median & 0.20 & 0.28 & 0.37 & 0.82 \\
\hline
\end{tabular}

Source: Authors' calculations based on AMADEUS data set (Annex 1).

In the case of Bulgaria, the continuation of SBCs and its relevance for the functioning of the financial sector, imply that in our estimation period, 1993-1996, the SBCs provided perverse incentives with respect to the allocation of external funds (notably bank loans). We will discuss this at length in Section 5 and we will find confirmation for this hypothesis. Here, we merely provide some input for this discussion by showing the financial indebtedness of loss-making firms, see Table 2. We do suspect that these companies faced SBCs with the result that they were able to attract more debt despite their losses. Table 2 shows the financial indebtedness (median and mean) of top 25 and top 100 loss-makers. We calculated means and medians for following ratios: LOSSK economic losses to long-term assets, LTDEBTK, long-term debt to long-term assets, STDEBTK, short-term debt to long-term assets, STDEBTAK, short-term debt arrears to long-term assets and LTDEBTAK, long-term debt arrears to long-term assets.

The long term debt to long-term assets ratio for top-25 loss makers increased during this period, except in 1995. The ratio of short-term debt to long-term assets increased nearly five-fold for this group of firms. This is evidence that these loss-makers had access to expensive short-term debt and were also rolling-over old long term debt. Note the excessive level of indebtedness of these loss-makers in 1996 - the year of the banking crisis. ${ }^{6}$ Regarding the top-100 loss-makers, their long-term debt to capital ratio dropped (most probably due to the write-off of bad debt). However, at the same time the ratio of short-term to long-term assets increased steadily and was also accompanied by an increase of short-term arrears ratio (not shown) during the same period.

\footnotetext{
${ }^{6}$ In fact, a large share of the short-term bank debt was in arrears in 1996.
} 
Table 2. The level of indebtedness of top-lossmakers

\begin{tabular}{|c|c|c|c|c|c|c|c|c|c|c|}
\hline & \multicolumn{2}{|c|}{1992} & \multicolumn{2}{|c|}{1993} & \multicolumn{2}{|c|}{1994} & \multicolumn{2}{|c|}{1995} & \multicolumn{2}{|c|}{1996} \\
\hline Top-25 lossmakers & MEAN & MED & MEAN & MED & MEAN & MED & MEAN & MED & MEAN & MED \\
\hline LOSSK$^{*}$ & 0.71 & 0.37 & 0.68 & 0.33 & 0.92 & 0.47 & 2.09 & 0.45 & 5.45 & 2.72 \\
\hline LTDEBTK & 0.76 & 0.28 & 0.74 & 0.27 & 1.08 & 0.02 & 0.45 & 0.01 & 1.77 & 0.00 \\
\hline STDEBTK & 0.46 & 0.24 & 0.21 & 0.12 & 0.65 & 0.10 & 2.93 & 0.07 & 0.68 & 0.03 \\
\hline STDEBTAK ** & 0.46 & 0.03 & 0.47 & 0.05 & 0.71 & 0.04 & 1.20 & 0.00 & 3.35 & 0.00 \\
\hline LTDEBTAK & 0.28 & 0.01 & 0.39 & 0.01 & 0.01 & 0.00 & 0.01 & 0.00 & 0.24 & 0.00 \\
\hline Top-100 lossmakers & MEAN & MED & MEAN & MEDI & MEAN & MED & MEAN & MED & MEAN & MEDI \\
\hline LOSSK* & 1.55 & 0.41 & 0.58 & 0.29 & 0.97 & 0.39 & 2.11 & 0.43 & 3.47 & 1.09 \\
\hline LTDEBTK & 2.70 & 0.26 & 0.66 & 0.13 & 0.87 & 0.01 & 0.29 & 0.00 & 0.68 & 0.00 \\
\hline STDEBTK & 0.55 & 0.20 & 0.29 & 0.13 & 0.56 & 0.10 & 1.36 & 0.14 & 0.71 & 0.08 \\
\hline STDEBTAK*** & 1.02 & 0.13 & 0.39 & 0.06 & 0.38 & 0.03 & 0.48 & 0.01 & 1.33 & 0.00 \\
\hline LTDEBTAK & 0.48 & 0.01 & 0.24 & 0.00 & 0.04 & 0.00 & 0.04 & 0.00 & 0.14 & 0.00 \\
\hline
\end{tabular}

* Note that for 1993-95 we have net loss as LOSS to Ltassets ratio, whereas for 1996 we had gross loss to ltassets ratio.

** Note that the STDEBTA/K ratio consist of total debt arrears for 1996, that is why the number is so large for 1996.

Source: Authors' calculations based on micro data set for 1993 - 1996, NSI, National Statistical Institute, Sofia, Bulgaria

The conclusion from this sub-section is that the problem with excessive debt was not just a stock problem but a flow problem as well, despite of all debt write-offs and high inflation, and that the origin of this flow problem is most probably the presence of SBCs in Bulgaria during the observed period. Berglof and Roland (1998) present a sequential model of SBCs of the bank-firm relations in transition economies. The SBCs create an incentive problem because the company will not exert high restructuring efforts if there are refinancing prospects instead of liquidation prospects. In this way, the SBCs create a moral hazard problem. In addition, banks can exhibit rent-seeking behavior. They can extract rents from the government by triggering bailouts. The latter is relevant in the case of Bulgaria, which means that in terms of the analysis of Berglof and Roland (1998) the so-called three-tier model is the case. Thus, in our interpretation of the estimation of the investment model with liquidity constraints, we must take into account that the foundation for the information problem underlying our version of equation (1) is different in case of Bulgaria compared to a typical Western market economy, since in case of Bulgaria the information problem has its origin in SBCs. 


\subsection{Data}

For our empirical analysis we use a data set with balance sheet and profit and loss accounts of 3000 Bulgarian industrial firms for the period 1993 - 1996. We have included only those firms that reported for the entire period 1993 - 1996, which gives us a balanced panel of 1003 fims. The data set is taken from the AMADEUS data base and the data are presented in millions of US $\$ .^{7}$ Because of the short time period, we used cross-section data for our analysis by averaging the variables in our data set. We did compute the average value of each variable for the full sample of 1003 companies over the period $1993-1995$. Due to the limited time period for which data are available we apply a cross section analysis on the averages of each variable. Estimating a dynamic investment model (hence taking the time series information into account) by using only three observations for each variable is misleading, since the adjustment process cannot be identified. Consequently, the coefficients we present refer to long-run average effects (Pesaran and Smith, 1994). This procedure of averaging along the time dimension is also used in similar studies in which the dataset covers only a few years (Lensink and Sterken, 1998 and Chirinko and Elston, 1997). We have excluded 1996 because of the severe financial crisis in this year, which distorted the data considerably.

All variables are thus expressed in US dollars. During the period 1993-1995, the dollar/leva rate fluctuated considerably (the leva depreciated by about 70\%). Such changes in the nominal exchange rate tend to dominate the results. We, therefore, corrected the nominal variables for changes in the real US dollar/leva rate (see Annex 2). Annex 1 provides a list of all the variables. Net investment, I, is the dependent variable in

\footnotetext{
${ }^{7}$ To be included in AMADEUS, a company must comply with one of the following size criteria: i., a turnover greater than Euro10 million; ii., a number of employees greater than 150; iii., total assets greater than Euro 10 million. Note that the AMADEUS data set presents the data in USD million. For more information on the data and the adjustments of data for fluctuations in USD/Leva exchange rate, see Annex 1 and Annex 2, respectively.
} 
the regressions, it is obtained as the first difference of tangible fixed assets. ${ }^{8}$ Investment opportunities, $\mathrm{X}$ in equation (1), are an important explanatory variable. Theoretically marginal $\mathrm{Q}$ could be used for the approximation of present and expected future investment opportunities. Since marginal Q is unobservable, many investment/liquidity studies for industrialized countries use average $\mathrm{Q}$ as a proxy. However, in order to be able to calculate average Q, the country concerned should have a well-developed stock market. In Bulgaria this is still not the case, and only a limited number of companies are listed. As a consequence for most Bulgarian firms average Q simply cannot be calculated. ${ }^{9}$ We therefore use the first differences of sales as a proxy for the investment opportunities of the firm. This proxy is also used in other studies on transition economies (see e.g. Lensink and Sterken, 1998) and does more often than not outperform Tobin's Q (Fazzari, Hubbard and Petersen (1988), pp. 165-175). Cash flow is used as a proxy for the liquidity variable in equation (1). ${ }^{10}$ So in our empirical study, equation (1) becomes

$$
(\mathrm{I} / \mathrm{K})_{\mathrm{i}}=\mathrm{c}_{\boldsymbol{0}}+\mathrm{c}_{1} \Delta(\mathrm{SAL}) / \mathrm{K}_{\mathrm{i}}+\mathrm{c}_{2} \mathrm{CF} / \mathrm{K}_{\mathrm{i}}+\varepsilon_{\mathrm{i}}
$$

where $\mathrm{i}$ denotes the $\mathrm{i}^{\text {th }}$ firm, $\mathrm{I}_{\mathrm{i}}$ is gross investment, $\triangle \mathrm{SAL}$ denotes the change in sales and proxies for investment opportunities, and CF represents the cash-flow variable., $\varepsilon_{\mathrm{i}}$ is the error term and $\mathrm{K}$, the scalar is the capital stock (at the beginning of each year).

The mean and median of most relevant variables ${ }^{11}$ for the full sample are presented in columns 1 and 2 of Table 3 . The considerable differences between the mean and the median of many variables indicate a skewed distribution. It turns out that there is a minority of very large firms (mainly (former) state owned enterprises) with many employees and a large capital stock. Columns 3-6 in Table 3 illustrate that firms with a

\footnotetext{
${ }^{8}$ Ideally, one would like to measure investment directly. However, as in all related studies the micro-data are based on the balance sheet of the firms, which leaves no other option then to proxy for investment by taking the first differences of the capital stock (see Fazari et al., 1998 and Hubbard, 1998).

${ }^{9}$ The use of an accelerator model of investment is open to the criticism that, as opposed to Tobin's Q, it does not deal sufficiently with expected profitability with the result that the liquidity variables in equation (1) might pick up this effect (see Hoshi et al, 1991).

${ }^{10}$ We experimented with other proxies for the liquidity variable, notably we also looked at the stock of liquidity, this proved immaterial to our results so in the remainder of the paper we stick to the use of cash flow as our proxy for the measurement of the impact of liquidity constraints on investment.

${ }^{11}$ All the variables in this data set are averages for the period $1993-1995$.
} 
negative cash flow do on average show a lower growth of sales, are more indebted than firms with a positive cash flow, which is consistent with the information in Section 3.1. Another important observation is that firms with positive cash flow had on average much smaller long-term debt than firms with negative cash flow.

Table 3 Summary Statistics for 1003 Bulgarian Firms

\begin{tabular}{l|rrrrrr}
\hline & TOTAL SAMPLE & \multicolumn{4}{c}{ CASH FLOW>0 } & \multicolumn{3}{c}{ CASH FLOW<0 } \\
\hline & MEAN & MEDIAN & MEAN & MEDIAN & MEAN & MEDIAN \\
NEMPL & 709 & 286 & 644 & 283 & 844 & 301 \\
K & 14.51 & 2.41 & 15.51 & 2.09 & 12.42 & 3.31 \\
IB/K & 0.25 & 0.19 & 0.26 & 0.20 & 0.22 & 0.17 \\
LTDEBT/K & 0.10 & 0.00 & 0.06 & 0.00 & 0.19 & 0.02 \\
LOAN/K & 0.58 & 0.30 & 0.46 & 0.25 & 0.82 & 0.46 \\
CREDIT/K & 0.16 & 0.07 & 0.17 & 0.06 & 0.16 & 0.08 \\
$\Delta($ SAL)/K & 1.18 & 0.69 & 1.47 & 0.89 & 0.58 & 0.38 \\
IPAY/K & 0.11 & 0.04 & 0.06 & 0.02 & 0.20 & 0.09 \\
CF/K & 0.06 & 0.04 & 0.19 & 0.08 & -0.21 & -0.09 \\
\hline
\end{tabular}

Variables description: NEMPL - number of employees, $K$ - tangible assets, $\mathrm{I}=\mathrm{d}(\mathrm{K})$ is the net investment, IB - gross fixed investment including depreciation, LTDEBT is the long term debt, NCLIAB - non-current liabilities, CLIAB - current liabilities, LOAN - short term loans, CREDIT - trade credit, d(SAL) proxies future profits, IPAY - interest paid, CF - cash flow.

All variables, except NEMPL (number of employees) and K (millions \$), are scaled by the capital stock K.

\section{Estimation Results for the Full Sample}

We estimate two versions of equation ( $1^{\prime}$ ) for the full sample. The first version is simply the accelerator model without the liquidity variable, whereas in the second version the cash-flow variable is added. Note that the variables used in all the regressions are scaled by the capital stock $\mathrm{K}$ in order to control for the size effect. The full sample estimation results are shown in Table 4 . The first column in table 4 represents the estimation of a neoclassical investment equation for Bulgarian companies, where investment only depends on the first difference of sales and capital market imperfections are thought to be absent. Although relatively small, the coefficient on first difference of sales is positive and significant. The second column estimates our liquidity constrained model of investment. The cash flow variable has a significant and positive impact on investment. ${ }^{12}$

\footnotetext{
${ }^{12}$ The size of the cash flow coefficient is relatively small but not extremely so. See for instance Hoshi et al. (1991), who using exactly the same methodology, find a cash flow coefficient of 0.1 for Japan.
} 
This suggests that liquidity constraints are relevant for the Bulgarian firms in our sample. $^{13}$

Table 4 Investment Accelerator Model estimated for the total sample

\begin{tabular}{|l|l|l|l|}
\hline Liquidity constraints model & $\begin{array}{l}\text { Neoclassical } \\
\text { Model }\end{array}$ & $\begin{array}{l}\text { Liquidity } \\
\text { Constrained }\end{array}$ & $\begin{array}{l}\text { Positive } \\
\text { Cash flows }\end{array}$ \\
\hline C Constant term & 0.227 & 0.232 & 0.238 \\
T-statistic & $(30.6)$ & $(30.43)$ & $(24.74)$ \\
Probability & $(0.0)$ & $(0.0)$ & $(0.0)$ \\
\hline$\Delta$ SAL/K First dif. sales to fixed capital & 0.019 & 0.014 & 0.01 \\
T-statistic & $(5.40)$ & $(3.42)$ & $(2.02)$ \\
Probability & $(0.0)$ & $(0.0)$ & $0.04)$ \\
\hline CF/K Cash Flow to fixed capital & & 0.034 & 0.053 \\
T-statistic & & $(2.43)$ & $(2.48)$ \\
Probability & & $(0.01)$ & $(0.01)$ \\
\hline Adjusted R ${ }^{2}$ & 0.0274 & 0.032 & 0.036 \\
\hline F-statistic & 29.185 & 17.61 & 13.57 \\
\hline Prob.(F-statistic) & 0.0 & 0.0 & 0.0 \\
\hline Number of companies & 1003 & 1003 & 678 \\
\hline
\end{tabular}

Numbers in brackets below the estimated coefficients are the t-ratios, standard errors are calculated as robust White-standard errors.

A considerable number of firms (325 out of 1003) in our sample have negative cash flows (see also Table 3). For these firms we expect that there is no relation between cash flows and investments: they are unable to finance investments with cash flow since these internal funds are simply lacking. As a consequence, companies with positive cash flows are expected to display a higher cash-flow coefficient compared to the full sample results. Reestimating equation ( 1 ') for these 678 (1003 minus 325) firms confirms our prior: the cash flow coefficient for the firms with a positive cash-flow is somewhat higher (3rd column in Table 4) compared to the CF-coefficient for the full sample. In the next sections, however, we continue to use the full-sample in our analysis. The main reason for doing this is that especially in transition economies firms with a negative cash flow also convey information about the way the financial system works. Note that the inclusion of firms with a negative cash flow in our estimations means that our results will be biased towards finding an insignificant cash-flow coefficient. For our present purposes we are more interested in our sub-sample estimations to which we now turn.

\footnotetext{
${ }^{13}$ To check for the sensitivity of our results for outliers, we have re-estimated every relation for a set excluding firms with negative investment to capital ratios, which can be considered as outliers in our dataset. This proved to be immaterial to our results.
} 


\section{Liquidity Constraints and the Relevance of Firms' Size and Debt}

In this section we use firm characteristics to classify firms that a priori can be considered to differ in their access to external funds or, in other words, in their liquidity constraints. Similar studies for industrialized countries focus on firm characteristics such as size, age, firms' relationships with banks, the dividend pay-out and leverage that can be used as criteria for sub-sampling. Some of these features are irrelevant for transition countries. All privately owned firms are young, so that age does not discriminate and there is no tradition with respect to dividend policy. A large part of the financial sector is often still owned by the state, and firm-level data on the linkages between the financial sector and the firms in our sample are simply lacking. Given these limitations we have selected the firm size (measured by the number of employees) as well as firms' (long term and shortterm) debt position as characteristics to split the sample. For firms in industrialized countries one would expect that size and debt are respectively positively and negatively correlated with liquidity constraints. If a firm is relatively large, one expects this to decrease the information costs for the external suppliers of funds and hence to decrease the external finance premium. A similar prior can be established for industrialized countries with respect to firms' debt position: liquidity constraints are assumed to matter more for firms with a relatively large stock of debt. ${ }^{14}$ In our sub-sample estimations we will argue, based on the discussion in Section 3.1, that these priors do not need to be relevant for a transition economy like Bulgaria to the extent that the relationship between a firm's size or debt on the one hand and the severenesss of liquidity constraints on the other hand may as well be reversed.

\subsection{Sample split based on firm size}

There are various measures to determine firm size. We present our estimations based upon the number of employees per firm. The mean for the number of employees (see

\footnotetext{
${ }^{14}$ Ideally one would only like to split the sample by using exogenous variables. Many of the criteria used in the literature to split the sample do, however, not meet this requirement. This is certainly the case for the debt variables, which are endogenous. As a result not only high but also low levels of debt may indicate financial problems. A high level of debt may ex ante indicate financial distress, but al low level may do so as well ex post since the latter could be the result of for instance credit rationing by the external suppliers of funds.
} 
Table 3) is 709, firms will be denoted as "small" ("large") if their average number of employees is below (above) this level. The result is that we have 818 small firms and 185 large firms. It is clear from the first column of Table 5 that the distribution of the number of employees is rather skewed (e.g. the difference between the mean and the median number of employees). This, of course, raises the question whether the mean should be taken as a cut-off value. We will return to this issue below.

Table 5 shows firms statistics for the whole sample and for the sub-samples of small and large firms.

Table 5 Large and Small Firms (based on the mean of number of employees).

\begin{tabular}{l|rrrrrr}
\hline & \multicolumn{3}{|l}{$\begin{array}{l}\text { TOTAL SAMPLE (1003 } \\
\text { firms })\end{array}$} & \multicolumn{4}{c}{$\begin{array}{l}\text { Sub-sample: SMALL } \\
\text { FIRMS }\end{array}$} & \multicolumn{3}{c}{ Sub-sample: LARGE firms $)$} & FIRMS (185 firms) \\
\hline & MEAN & MEDIAN & MEAN & MEDIAN & MEAN & MEDIAN \\
NEMPL & 709 & 286 & 297 & 252 & 2529 & 1308 \\
K & 14.51 & 2.41 & 3.45 & 1.75 & 63.4 & 15.1 \\
IB/K & 0.25 & 0.19 & 0.25 & 0.19 & 0.27 & 0.21 \\
LTDEBT/K & 0.10 & 0.00 & 0.09 & 0.00 & 0.16 & 0.03 \\
LOAN/K & 0.58 & 0.30 & 0.57 & 0.29 & 0.62 & 0.34 \\
CREDIT/K & 0.16 & 0.07 & 0.16 & 0.06 & 0.17 & 0.11 \\
$\Delta($ SAL)/K & 1.18 & 0.69 & 1.22 & 0.69 & 1.00 & 0.68 \\
IPAY/K & 0.11 & 0.04 & 0.11 & 0.03 & 0.11 & 0.06 \\
CF/K & 0.06 & 0.04 & 0.07 & 0.04 & 0.02 & 0.03 \\
\hline
\end{tabular}

All variables are scaled by the capital stock K, except NEMPL (number of employees) and $\mathrm{K}$ (US\$ millions)

On average small firms have first of all a lower investment to capital ratio than the large firms. Secondly, small firms have less long-term debt. During the estimation period and in line with policies in the pre-transition period, Bulgarian banks mostly extended uncollateralized loans. After the transition began, many firms simply stopped servicing their debts. In such cases any extended long-term debt is equivalent to a subsidy. Hence, the term soft budget constraint is appropriate to describe such a situation which, see 3.1 , applied to many (formerly) state-owned firms which are typically represented by the large firms in our sample. ${ }^{15}$ Third, small firms have a higher cash flow to capital ratio.

\footnotetext{
${ }^{15}$ Since a majority of these companies were state-owned and there were no clear bankruptcy procedures put in place, these companies were surviving through the loans extended by the banks. Unfortunately, we do
} 
Claessens and Peters (1997) concluded that the biggest losses are concentrated within the largest firms, which is in accordance with Table 5.

Table 6 Estimation of the investment equation with liquidity constraints

\begin{tabular}{|l|l|l|}
\hline Dependent variable & Small firms & Large firms \\
IB/K Gross investment & & \\
\hline C, Constant term & 0.229 & 0.227 \\
T-statistic & $(27.37)$ & $(11.34)$ \\
Probability & $(0.00)$ & $(0.00)$ \\
\hline$\Delta$ SAL/K , First diff. of sales to capital & 0.013 & 0.042 \\
T-statistic & $(2.87)$ & $(2.78)$ \\
Probability & $(0.00)$ & $(0.006)$ \\
\hline CF/K Cash Flow to capital & 0.034 & 0.097 \\
T-statistic & $(2.36)$ & $(1.49)$ \\
Probability & $(0.018)$ & $(0.137)$ \\
\hline Adjusted R ${ }^{2}$ & 0.031 & 0.064 \\
\hline F-statistic & 14.22 & 7.33 \\
\hline Prob.(F-statistic) & 0.0 & 0.0 \\
\hline Sample size: $1993 / 95$ & 818 companies, & 185 companies \\
& NEMPL<709 & NEMPL>709 \\
\hline
\end{tabular}

Numbers in brackets below the estimated coefficients are the t-ratios. Standard errors are robust Whitestandard errors.

Table 6 presents the estimation results for equation (1') for small and large firms. The first column shows that the cash flow coefficient is positive and significant for the small firms. The second column presents the estimation results for large firms. For these firms we obtained an insignificant cash flow coefficient. Again, this is in line with the idea that large firms are less profitable (lower cash flow) and thus have relatively less internal funds at their disposal to finance their investment. This need not to be a problem for these firms for they can rely relatively more upon external funds. Whether this reliance does reflect lower information costs, as one would expect in the case of large firms in "Western" economies, or simply the inheritance from the centrally planned economy of an inefficient financial sector and the continuation of soft budget constraints remains an open question. One should, however, be careful and not overemphasize the difference

not have any information on the banks that have extended these loans. Dobrinski (1996), however, gives information about the segmentation of the banking sector in bad (consisting of predominantly state-owned banks that have large part of non-performing loans in their portfolios) and good (consisting mainly of newly created private banks which did not have such loans in their portfolios). 
between the cash-flow coefficient for small and large firms given that this difference, though significant, is not very large. ${ }^{16}$

\subsection{Sample split based on long-term and short-term debt}

For investment studies of Western economies the intuition behind such a sample-split is mostly that companies with a relatively large amount of debt are more likely (ex ante) to face liquidity constraints. In this sub-section we first look at a sample-split based on longterm debt and we subsequently split the sample using short-term debt.

From Tables 3 and 5 it could be discerned that there are notable differences among the firms in our sample with respect to the stock of long term debt. The sample is split based on the criterion whether a firm has any long-term debt on its balance sheet or not. As can be seen from Table 8 long term debt is predominantly held by larger firms and by firms with a negative(!) cash flow. Table 7 presents the estimation results.

Table 7 Estimation of the investment equation using long-term debt for sub-sampling

\begin{tabular}{|l|l|l|}
\hline Dependent variable & Companies with positive & Companies without LT debt \\
IB/K Gross investment & LT debt & \\
\hline C Constant term & 0.225 & 0.234 \\
T-statistic & $(20.79)$ & $(21.16)$ \\
Probability & $(0.00)$ & $(0.00)$ \\
\hline$\Delta$ SAL/K First dif. of sales to fixed capital & 0.022 & 0.012 \\
T-statistic & $(2.89)$ & $(2.21)$ \\
Probability & $(0.004)$ & $(0.0275)$ \\
\hline CF/K Cash Flow to fixed capital & 0.032 & 0.0356 \\
T-statistic & $(1.14)$ & $(2.13)$ \\
Probability & $(0.252)$ & $(0.0335)$ \\
\hline Adjusted R ${ }^{2}$ & 0.0295 & 0.032 \\
\hline F-statistic & 8.296 & 9.618 \\
\hline Prob.(F-statistic) & 0.000 & 0.000 \\
\hline Sample size: $1993 / 95$ & 481 companies & 522 companies \\
& LTDEBT/K>0 & LTDEBT/K=0 \\
\hline
\end{tabular}

Numbers in brackets below the estimated coefficients are the t-ratios. Standard errors are robust White standard errors.

The estimation results suggest that firms that have no long-term debt at all are liquidity constrained whereas firms with long-term debt are not. For Bulgarian firms it is the case

\footnotetext{
${ }^{16}$ In order to investigate the sensitivity of the results for the cut-off value of NEMP=709 we ran regressions for the whole range of NEMPL. It turned out that the cut-off value of 700 has the best fit and still the largest difference between the 2 cash-flow coefficients. The mean of the sample (NEMPL=709) is close to this value, so this suggests that mean of NEMPL is an appropriate cut-off value.
} 
that firms with a positive long-term debt are on average relative large, do not make a profit and display a lower (sales) growth (see Table 8). As a consequence, and this confirms our results based on the size criterion, firms with a positive long-term debt are financially in a relatively weak position and cannot draw upon internal funds for the financing of their investment (e.g. the negative cash flow to capital ratio in Table 8). But, and here's the connection with the SBCs, they were nevertheless able to attract external funds. Firms without long-term debt simply do look healthier. Hence, a positive longterm debt might be considered as a sign of financial weakness in the case of Bulgaria. ${ }^{17}$

Table $8 \quad$ Bulgarian Firms and Long Term Debt.

\begin{tabular}{l|rrrr}
\hline & LTDEBT>0 & \multicolumn{4}{c}{ LTDEBT=0 } \\
\hline & MEAN & MEDIAN & MEAN & MEDIAN \\
NEMPL & 982 & 370 & 457 & 255 \\
K & 23.4 & 3.68 & 6.32 & 1.66 \\
IB/K & 0.25 & 0.19 & 0.26 & 0.19 \\
LTDEBT/K & 0.22 & 0.06 & 0.00 & 0.00 \\
LOAN/K & 0.56 & 0.32 & 0.59 & 0.28 \\
CREDIT/K & 0.16 & 0.07 & 0.17 & 0.06 \\
$\Delta(\mathrm{SAL}) / \mathrm{K}$ & 0.93 & 0.59 & 1.42 & 0.81 \\
IPAY/K & 0.13 & 0.07 & 0.09 & 0.01 \\
CF/K & -0.01 & 0.01 & 0.12 & 0.06 \\
\hline
\end{tabular}

Finally, we discuss the estimation results from the sample-split based on short-term debt. In 3.1 it was concluded (based on Tables 1 and 2) that Bulgarian firms increased their short-term debt considerably in the period under consideration and that this increase was especially marked for loss-making firms. We therefore re-estimated equation (1') for a sample split based on both long-term and short-term debt because this probably gives a better indication of the financial structure of the Bulgarian firms.

Table 9 presents the estimation results. For short-term debt, we use the ratio shortterm loans to capital, see Annex 1, and the cut-off value is the mean for this variable, 0.58. As the first column of Table 9 shows the cash-flow coefficient is clearly not significant for the firm with a positive long-term debt and above average short-term debt.

\footnotetext{
17 Fan, Lee and Schaffer (1996) provided an evidence for adverse selection in Russia: the firms that hold bank debt were on average less healthy than the average in their sample.
} 
In fact, the perfect capital markets model fits better for this sub-sample. ${ }^{18}$ The second column gives the results for those firms with short-term debt ratio of less then 0.58 , whereas the third sub-sample, see third column in Table 9, adds the restriction that these firms also have no long-term debt whatsoever.

Table 9 Investment equation using long-term and short-term debt for sub-sampling

\begin{tabular}{|c|c|c|c|}
\hline $\begin{array}{l}\text { Dependent variable } \\
\text { IB/K }\end{array}$ & $\begin{array}{l}\text { Companies with } \\
\text { LT debt }>0 \text { and } \\
\text { ST debt }>0.58\end{array}$ & $\begin{array}{l}\text { Companies with } \\
\text { ST debt }<0.58\end{array}$ & $\begin{array}{l}\text { Companies without LT debt } \\
\text { and with ST debt }<0.58\end{array}$ \\
\hline $\begin{array}{l}\text { C Constant term } \\
\text { T-statistic } \\
\text { Probability }\end{array}$ & $\begin{array}{l}0.243 \\
(9.30) \\
(0.00) \\
\end{array}$ & $\begin{array}{l}0.213 \\
(22.71) \\
(0.00) \\
\end{array}$ & $\begin{array}{l}0.205 \\
(14.35) \\
(0.00) \\
\end{array}$ \\
\hline $\begin{array}{l}\Delta \mathrm{SAL} / \mathrm{K} \\
\mathrm{T} \text {-statistic } \\
\text { Probability }\end{array}$ & $\begin{array}{c}0.017 \\
(1.36) \\
(0.176)\end{array}$ & $\begin{array}{c}0.021 \\
(2.50) \\
(0.0125)\end{array}$ & $\begin{array}{l}0.023 \\
(1.77) \\
(0.077)\end{array}$ \\
\hline $\begin{array}{l}\text { CF/K } \\
\text { T-statistic } \\
\text { Probability }\end{array}$ & $\begin{array}{l}0.027 \\
(0.73) \\
(0.468) \\
\end{array}$ & $\begin{array}{l}0.166 \\
(4.31) \\
(0.00) \\
\end{array}$ & $\begin{array}{l}0.171 \\
(3.46) \\
(0.00) \\
\end{array}$ \\
\hline Adjusted $\mathrm{R}^{2}$ & 0.0324 & 0.058 & 0.0746 \\
\hline F-statistic & 3.0417 & 23.94 & 16.595 \\
\hline Prob.(F-statistic) & 0.0514 & 0.000 & 0.000 \\
\hline Sample size: $1993 / 95$ & 123 companies & 746 companies & 388 companies \\
\hline
\end{tabular}

Numbers in brackets below the estimated coefficients are the t-ratios. All standard errors are robust-Whitestandard errors.

As the coefficients in columns 2 and 3 illustrate, the cash-flow coefficient is not only clearly significant but the size of the cash-flow coefficient is relatively large and the difference with this coefficient reported in the first column is noteworthy. The size of the coefficient is in line with results found by others (see Fazzari et al., 1988 and Hubbard, 1998). The importance of these estimation results is underlined by the variables presented in Table 10. This table shows that on average, the group of highly indebted companies has a negative cash flow. These are also companies that have an investment to capital ratio higher than the liquidity constrained companies, larger total assets and, most importantly, an extremely high level of both long-term (LTDEBTK is 0.34) and notably short-term debt (LOANK is 1.43). For the liquidity constrained firms (see 2nd and 3rd column in Table 10) the ratios for both long-term and short-term debt are much lower. The first group of firms (with thus a negative cash-flow, mean and median) consists of 123 firms which seems to be consistent with the finding of Claessens and Peters (1997)

\footnotetext{
${ }^{18}$ The regression result is as follows: $\mathrm{I} / \mathrm{K}=0.23+0.0225 \Delta(\mathrm{SALES}) / \mathrm{K}$
}

$$
\mathrm{R}^{2}=0.044 \quad(10.8)(2.36)
$$


that losses are concentrated in about 100 (formerly) state-owned companies in Bulgaria during this period.

Table 10 Bulgarian firms and the role of short-term credit and long-term debt.

\begin{tabular}{l|crrrrr}
\hline & \multicolumn{2}{|c}{$\begin{array}{c}\text { ST loans }>0.58 \\
\text { LTdebt }>0\end{array}$} & \multicolumn{2}{c}{ ST loans $<0.58$} & \multicolumn{2}{c}{ ST loans $<0.58$} \\
LTdebt $=0$
\end{tabular}

The findings in Section 5 and in particular in Tables 9 and 10 are evidence of the inefficiencies in Bulgaria in our view and they can only be explained if somehow SBCs are taken into account. First, firms which made losses were not liquidity constrained and thanks soft-budget constraints were still able to draw (increasingly) upon external funds. Second, firms with on average a positive cash-flow and relatively low levels of debt are liquidity constrained. In fact, what our regressions for the various sub-samples show is that imprudent (insolvent) borrowers had access to external finance which was not only due to SBCs. The continued access to external finance reinforced the problems associated with SBCs and increased the moral hazard problem which was at the root of financial crisis of 1996 and 1997. In this sense our empirical findings support the theoretical analysis of SBCs in Berglof and Roland (1998) and Dewatripont and Roland(1999).

\section{Conclusions}

In this paper we have used a simple accelerator model of investment for a sample of 1003 Bulgarian firms for the period 1993-1995. This model is augmented by a liquidity variable in order to investigate whether or not firms are liquidity constrained. During our sample period (public) financial markets in Bulgaria were underdeveloped so that we expect that Bulgarian firms are liquidity constrained. The estimates for our entire sample confirm this prior. On the other hand, it is also well known that during these years 
Bulgarian banks were generously financing loss-making firms. Our sub-sample estimation results with sample splits based on firm size and firm debt are consistent with the idea that soft-budget constraints are (still) important in understanding the behavior of borrowers and lenders (mainly banks) in the case of Bulgaria. It appears that the investment of relatively large firms was not liquidity constrained but that the opposite holds for smaller firms. Firms with a relatively small long-term and short- term debt, respectively those with positive cash flows also appeared to be liquidity constrained whereas heavily indebted firms, respectively firms with a negative cash flow, were not liquidity constrained. All in all, our results indicate that in the transition period 19931995 in Bulgaria the information problems associated with soft- budget constraints were very important. In empirical studies for Western economies, the insignificance of liquidity constraints for firm investment is interpreted as a sign that these companies are facing a lower external finance premium and hence smaller problems of asymmetric information. In the case of Bulgaria the conclusion must be that the absence of liquidity constraints also points to a lower external finance premium but for a very different reason. In a setting of soft budget constraints for the demand and supply of external funds the absence of liquidity constraints may very well imply a rather inefficient financial sector and severe problems of asymmetric information that arise from the soft budget constraints. An important topic for further research is to see whether our results for Bulgaria also hold for other transition economies. 
ANNEX 1: Variables Description: Bulgarian Microdata, period 1993 - 1995

Firms with missing observations were first deleted. Then we averaged all variables for the period 93/95. The only variables which we first calculate as the first difference and then averaged were investment, $\boldsymbol{I}$, which is obtained as a first difference of tangible fixed assets, and the first difference of sales, $\boldsymbol{D S A L}$.

All the variables are expressed in USD million.

Data available for Bulgaria in AMADEUS:

\section{Balance sheet}

Assets

Liabilities

Tangible fixed assets

Shareholders funds

Fixed assets

Long term debt

Stocks

Debtors

Cash \& cash equivalent

Non-current liabilities

Total assets

Current liabilities

Working capital

Number of employees

Loans

Creditors

Profit and Loss account

Sales

Gross profit

P/L before tax

Taxation

Costs of employees

Depreciation

Interest paid

Cash flow

1. The following variables have been averaged over the period of observation:

K tangible assets,

LTDEBT long term debt;

LOAN short term loans;

CREDIT trade credits;

WCAP working capital;

NEMP number of employees;

PLBTAX profit and loss before tax;

TAX taxation;

DEP depreciation;

IPAY interest paid;

CF cash flow (equals before-tax profits plus depreciation, DEP),

2. The following variables were obtained first as differences and then were they averaged for the period of observation:

$\mathbf{I}=\mathbf{d}(\mathbf{K})$, investment; $\mathbf{D}(\mathbf{S A L})$, first difference of sales

$\mathrm{I}($ Investment $)=\mathrm{d}($ Tangible fixed assets $), \mathrm{IB}=\mathrm{I}+\mathrm{DEP}, \mathrm{IBK}=\mathrm{IB} / \mathrm{K}, \mathrm{DSAL}=\mathrm{D}($ Sales $) ; \mathrm{DSAL} 1=\mathrm{DSAL} / \mathrm{K}$, $\mathrm{DCF}=\mathrm{CF} / \mathrm{K}$ 


\section{ANNEX 2: Adjustment of Data Set for Inflation and Exchange rate changes}

Since this data set was available in AMADEUS only in USD million (in current USD) we had to adjust for fluctuations of inflation rate and nominal exchange rate. A serious problem with this data set, is the fact that all the data are expressed in current dollar prices. Such an approximation of real values by the use of dollar values can only be useful for countries with a stable exchange rate with respect to the dollar and an inflation rate close to the US inflation rate. When the exchange rate fluctuations are large and inflation rate is high and variable, variables, such as investment and first difference in sales will represent not only quantity but also valuation effects. We will show that valuation effects are substantial for the Bulgarian case so these should be eliminated.

Large fluctuations in the nominal exchange rate (EXR) imply that if data are measured in current USD prices, the changes in variables (investment) will pick up not only quantity changes but valuation changes as well. One way to exclude the valuation changes was to convert the data to be measured in constant dollar prices. We calculated the constant dollar values for each variable, $\mathrm{X}$ as follows: $\mathrm{X}_{\mathrm{t}} \cdot\left(\mathrm{EXR}_{\mathrm{t}+\mathrm{i}}\right.$ $/ \mathrm{EXR}_{\mathrm{t}}$ ) where $\mathrm{t}$ is 1993 and $\mathrm{i}$ is year 0,1,2 (see the third and fourth columns of Table A.1).

The constant dollar value approach is sufficient if PPP holds. The real exchange rate, however, varyied substantially during the period 1993 - 1996. The significant real appreciation during 1994 and 1995 distorts the data set even when expressed in constant dollars, because the assets value in dollars would be lower than when expressed in domestic currency. To correct for this problem, we corrected the constant dollar values for changes in relative prices (IE), as follows: $\mathrm{X}_{t} \cdot\left(\mathrm{EXR}_{\mathrm{t}+\mathrm{i}} / \mathrm{EXR}_{\mathrm{t}}\right) / \mathrm{IE}_{\mathrm{t}+\mathrm{i}}$ where $\mathrm{t}$ is 1993 and $\mathrm{i}$ is year $0,1,2$. After that we compute net investment and first difference of sales and then we average all the variables over the period 1993 - 1995 (see the first two columns of Table A2.1). Table A 2.1. illustrates clearly the importance of correcting for real exchange rate fluctuations. This is especially true for the investment series. In current dollar prices both mean and median investmant are negative, while this is no longer the case once investment is expressed in real dollar prices.

Table A2.1 Bulgarian Company Data, AMADEUS, USD million

\begin{tabular}{l|rrrrrrr}
\hline & Real Dollar Prices & \multicolumn{3}{c}{ Constant Dollar Prices } & \multicolumn{3}{c}{ Current Dollar Prices } \\
\hline & MEAN & \multicolumn{2}{|c}{ MEDIAN } & MEAN & MEDIAN & MEAN & MEDIAN \\
NEMPL & 709 & 286 & 709 & 286 & 709 & 286 \\
K & 14.51 & 2.41 & 12.42 & 2.07 & 7.896 & 1.33 \\
I & 3.88 & 0.35 & 1.34 & -0.03 & -2.409 & -0.52 \\
IB & 4.67 & 0.53 & 2.01 & 0.09 & -1.999 & -0.438 \\
LTDEBT & 1.62 & 0.00 & 1.42 & 0.00 & 0.911 & 0.000 \\
CLIAB & 7.92 & 1.06 & 6.54 & 0.88 & 3.751 & 0.517 \\
LOAN & 5.25 & 0.65 & 4.34 & 0.56 & 2.494 & 0.337 \\
CREDIT & 1.96 & 0.15 & 1.61 & 0.13 & 0.917 & 0.073 \\
DSAL & 8.44 & 1.42 & 8.45 & 1.41 & 0.999 & 0.075 \\
IPAY & 0.88 & 0.09 & 0.75 & 0.08 & 0.461 & 0.053 \\
CF & 0.15 & 0.07 & 0.11 & 0.05 & 0.022 & 0.027 \\
\hline Vara
\end{tabular}

Variables description: NEMPL - number of employees, $\mathbf{K}$ - tangible assets, $\mathbf{I}=\mathbf{d}(\mathbf{K})$ is the net investment, IB - gross fixed investment including depreciation, LTDEBT is the long term debt, NCLIAB - noncurrent liabilities, CLIAB - current liabilities, LOAN - short term loans, CREDIT - trade credit, d(SAL) proxies future profits, IPAY - interest paid, CF - cash flow. 
ANNEX 3: Bulgarian Company Data, AMADEUS, USD million

Table A3.1 Main Characteristics of Bulgarian Company Data

\begin{tabular}{l|rrrrrr}
\hline & TOTAL SAMPLE & \multicolumn{4}{c}{ SMALL COMPANIES } & BIG COMPANIES \\
\hline & MEAN & MEDIAN & MEAN & MEDIAN & MEAN & MEDIAN \\
NEMPL & 709 & 286 & 209 & 205 & 1212 & 540 \\
K & 14.51 & 2.41 & 1.92 & 1.23 & 27.18 & 6.20 \\
I & 3.88 & 0.35 & 0.31 & 0.16 & 7.47 & 0.92 \\
IB & 4.67 & 0.53 & 0.42 & 0.23 & 8.95 & 1.29 \\
LTDEBT & 1.62 & 0.00 & 0.14 & 0.0 & 3.12 & 0.03 \\
LOAN & 5.25 & 0.65 & 0.73 & 0.29 & 9.80 & 1.74 \\
CREDIT & 1.96 & 0.15 & 0.22 & 0.07 & 3.70 & 0.42 \\
DSAL & 8.44 & 1.42 & 1.29 & 0.80 & 15.63 & 3.13 \\
IPAY & 0.87 & 0.09 & 0.16 & 0.03 & 1.60 & 0.27 \\
CF & 0.155 & 0.07 & 0.008 & 0.04 & 0.30 & 0.15 \\
\hline
\end{tabular}

Table A3.2 External Financing, Bulgarian Company Data, AMADEUS, USD million

\begin{tabular}{|c|c|c|c|c|c|c|}
\hline & \multicolumn{2}{|c|}{ TOTAL SAMPLE } & \multicolumn{2}{|c|}{ SMALL COMPANIES } & \multicolumn{2}{|c|}{ BIG COMPANIES } \\
\hline & MEAN & MEDIAN & MEAN & $\overline{\mathrm{AN}}$ & MEAN & \\
\hline LOAN & 5.25 & 0.65 & 0.73 & 0.29 & 9.80 & 1.74 \\
\hline LOAN/K & 0.58 & 0.30 & 0.56 & 0.28 & 0.59 & 0.33 \\
\hline LTDEBT & 1.62 & 0.0 & 0.14 & 0.0 & 3.12 & 0.03 \\
\hline LTDEBT/K & 0.10 & 0.0 & 0.08 & 0.0 & 0.13 & 0.07 \\
\hline CREDIT & 1.96 & 0.15 & 0.22 & 0.07 & 3.70 & 0.42 \\
\hline CREDIT/K & 0.17 & 0.07 & 0.17 & 0.06 & 0.17 & 0.08 \\
\hline SHAREH & 13.32 & 2.33 & 1.97 & 1.28 & 24.74 & 5.46 \\
\hline SHAREH/K & 1.14 & 1.06 & 1.25 & 1.12 & 1.02 & 1.01 \\
\hline
\end{tabular}




\section{References}

Anderson, R. and C. Kegels (1997), 'Finance and Investment in Transition: Czech Enterprises, 1993-1994', mimeo, CERGE, Prague.

Åslund, A., P. Boone and S. Johnson (1996), 'How to stabilize' Brookings Papers on Economic Activity, 1, pp. 217-313.

Berglof, E. and G. Roland (1998), 'Soft Budget Constraints and Banking in Transition Economies', Journal of Comparative Economics, 26(1), pp. 18-40.

Bonin, J. and I. Szekely (1994), The Development and Reform of Financial Systems in Central and Eastern Europe, Edward Elgar Publishing Limited, England

Bonin, J. (1993), 'On the Way to Privatizing Commercial Banks: Poland and Hungary Take Different Roads', Comparative Economic Studies, 35, 103-119

Boot, A. and S. van Wijnbergen (1995), 'Financial Sector Design, Regulation and Deposit Insurance in Eastern Europe' in J. Rostowski edd., Banking Reform in Central Europe and the Former Soviet Union, Central European University Press, Budapest, Hungary

Chirinko, R.S. and J.A. Elston (1997), 'Finance, Control, and Profitability: The Influence of German Banks', mimeo.

Claessens, S. (1997), 'Banking Reform in Transition Countries', World Development Report, 1996, World Bank.

Claessens, S. and R. Peters (1997), 'State Enterprise Performance and Soft Budget Constraints: The Case of Bulgaria', Economics of Transition, 5(2), pp. $305-322$.

Claessens, S. and G. Pohl (1998), 'The Restructuring of Large Firms in the Slovak Republic', Economics of Transition, 6 (1), pp. 67 - 85.

Claessens, S. and S. Djankov (1998), 'Politicians and Firms in Seven Central and Eastern European Countries', the World Bank PPRA paper...

Corbett, J. and C. Mayer (1991), 'Financial Reform in Eastern Europe: Progress with the Wrong Model', Oxford Review of Economic Policy, 7(4).

Dewatripont, M. and G. Roland (1999), 'Soft Budget Constraints, Transition and Finacial Systems', mimeo.

Dobrinsky, R. (1996), 'Monetary Policy, Macroeconomic Adjustment and Currency Speculation under Floating Exchange Rates: the case of Bulgaria', Economics of Transition, 4(1) 185 - 210 
Dobrinsky, R. (1997), 'Transition Failures: Anatomy of the Bulgarian Crisis', Paper prepared for the ACE Workshop on Exchange Rate and Capital Flows in Transition Economies, Sofia .

Dobrinsky, R., N. Dochev and B. Nikolov, (1997), 'Debt Workout and Enterprise Performance in Bulgaria: Lessons from Transition Experience and Crisis', CERT Discussion Paper, No. 97/15.

Ees, H. van and H. Garretsen (1994), 'Liquidity and Business Investment: Evidence from Dutch Panel Data', Journal of Macroeconomics, 16 (4).

Ees, H. van, H. Garretsen, L. de Haan and E. Sterken (1996), 'Investment and Debt Constraints: Evidence from Dutch Panel Data, SOM Research Report 96E39.

Fan, Q., U. Lee and M. Schaffer (1996), 'Firms, Banks, and Credit in Russia', CERT.

Fazzari, S., G. Hubbard, and B. Petersen (1988), 'Financing Constraints and Corporate Investment', Brookings Papers on Economic Activity, 1, 1988.

Fazzari, S., G. Hubbard, and B. Petersen (1988), 'Tax Policy and Investment: a Reconsideration', American Economic Review, 78(2).

Griffith-Jones, S. and Drabek, Z. (1995), Financial Reform in Central and Eastern Europe, St. Martin's Press, New York, USA

Hoshi, T., A. Kashyap and D. Scharfstein (1991), 'Corporate Structure, Liquidity, and Investment: Evidence from Japanese industrial groups' Quarterly Journal of Economics, 106 (February), pp. 33-59.

Hubbard, G. (1998), 'Capital-Market Imperfections and Investment', Journal of Economic Literature, 36(March), pp. 193 - 225.

IMF (1997), 'IMF Concludes Article IV Consultation with Bulgaria', IMF Press Information Notice Number 97/15.

Kornai, J. (1997), 'The Place of the Soft Budget Constraint Syndrome in Economic Theory', Journal of Comparative Economics, 26(1), pp. 11-17.

Lensink, R. and E. Sterken (1998), 'Investment, Financing, and Uncertainty in Estonia', mimeo, University of Groningen .

Lizal, L. (1996), 'The Dynamics of Enterprise Investment and Export Behavior in Transition Period', mimeo, CERGE, Prague.

Manchev, T. (1996), 'Aspects of Financial Crisis in Bulgaria, 1991 - 1995', mimeo, Sofia, Bulgaria. 
Manchev, T., I. Iskrov and A. Mihailov (1998), Money, Banks and Monetary Policy, Sofia 1998, Bulgaria.

Nenova, M., N. Micheva and T. Manchev (1996), 'Financial Policy in Bulgaria during Transition to market Economy', Sofia, Bulgaria, mimeo.

Perotti, E.C. and S. Gelfer, 1997, 'Investment and Financing in Russian Financial Industrial Groups', mimeo, University of Amsterdam.

Pesaran, M.H. and R. Smith (1994), ' Estimating Long-run Relationships from Dynamic Heterogenous Panels', mimeo, University of Cambridge.

Pinto, B., M. Belka and S. Krajewski (1993), 'Transforming State Enterprises in Poland: Evidence on Adjustment by Manufacturing Firms', Brookings Papers on Economic Activity 1, pp. 213-290.

Pinto, B. and S. van Wijnbergen, 1994, 'Ownership and Corporate Control in Poland: Why State Firms Defied the Odds, International Finance Corporation', Policy Research Working Paper 1308.

Rostowski, J (1995), Banking Reform in Central Europe and the Former Soviet Union, Central European University Press, Budapest, Hungary

Schaffer, M. (1998), 'Do Firms in Transition Economies have Soft Budget Constraints? A Reconsideration of Concepts and Evidence', Journal of Comparative Economics, 26(1), pp. 80-103.

Scholtens, B. (1997), 'The Experience with Financial System Architecture in Central Europe', mimeo, University of Amsterdam.

Stiglitz, J. and Weiss, A. (1981), 'Credit Rationing in Markets with Imperfect Information', American Economic Review, 71(3), pp.393 - 410.

Thorne, A. (1993), 'Eastern Europe's Experience with Banking Reform: is there a Role for Banks in the Transition?', Journal of Banking and Finance, 17, 959-1000 